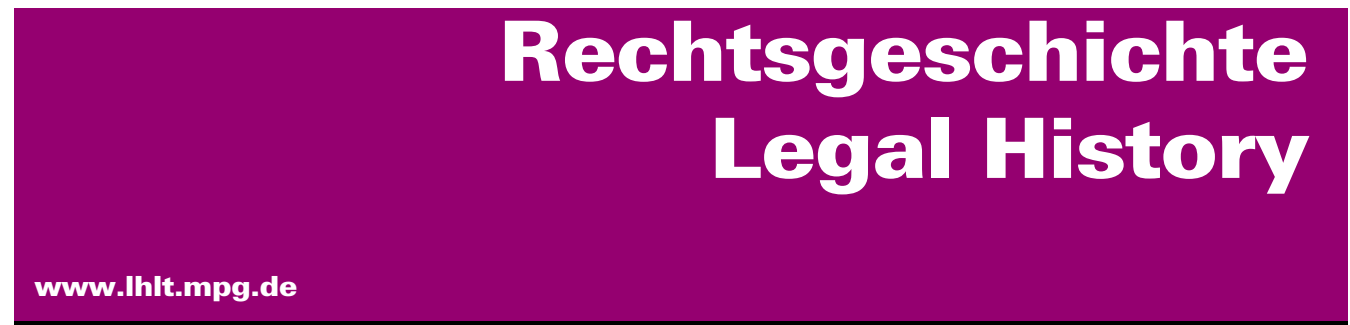

http://www.rg-rechtsgeschichte.de/rg29

$\operatorname{Rg} 292021 \quad 92-98$

Zitiervorschlag: Rechtsgeschichte - Legal History Rg 29 (2021)

http://dx.doi.org/10.12946/rg29/092-098

\title{
Manuela Bragagnolo*
}

\section{Books in Motion and Normative Knowledge Production in the Early Modern Iberian Worlds. An Introduction}

* Università degli Studi di Trento, Scuola di Studi Internazionali / Max Planck Institute for Legal History and Legal Theory, Frankfurt am Main, manuela.bragagnolo@unitn.it; bragagnolo@lhlt.mpg.de 


\section{Manuela Bragagnolo}

\section{Books in Motion and Normative Knowledge Production in the Early Modern Iberian Worlds. An Introduction*}

How was normative knowledge produced in the early modern period? One obvious way to answer this question is to study the contents of legal books. But we can also look at these books as material objects. This second approach invites us to consider that knowledge was also the result of material and social processes of production. ${ }^{\mathbf{1}}$ It also means having a broader look at legal materiality more generally. ${ }^{2}$

»Medieval and early modern learned law« was »deeply rooted in a literary tradition «, and every »development of legal learned knowledge« was »embedded in the written page«. In medieval and early modern learned circles, "to master the law was to read books". But, most importantly, the materiality of books does »carry meaning ${ }^{3}{ }^{3}$ With these words, António Manuel Hespanha in 2008 stressed the need to expand the scope of legal historical research, which had, up to that point, traditionally focused on the intellectual output of the so-called rauthor $\triangleleft$ In the article, Hespanha demonstrated the strong connection between the development of early modern Western legal theory and the changes in the physical format of the book, specifically in the layout of the printed page. On the basis of this, he proposed taking into account the interconnections between the content and the materiality of the objects that contributed - maybe more than other forms of media - to the storage, mobilisation and communication of normative knowledge: books, specifically legal books. ${ }^{4}$ In this way, Hespanha tried to bridge the gap between »material bibliography and legal history«. This gap was not only methodological, but also one between two branches of knowledge - book history and legal history - which largely ignored one another, with only few exceptions, for a long time. $^{5}$

In the last decades, a >Copernican shift in book studies saw attention move from the rauthor to the sreader<, opening up new areas of research. This shift has greatly affected the fields of history of knowledge and history of science, and, more recently, has begun to have an impact on legal history as well. ${ }^{6}$ Legal historians have begun taking the materiality of legal books seriously. They have started to analyse law in the past as a broader cultural phenomenon by looking at legal books, paying particular attention to legal knowledge, legal culture and legal literacy as well as to the readers of legal books, in different geographical areas.

For instance, along with a renewed interest in those >doctrinal legal books that most influenced Western legal culture in the age of print, ${ }^{7}$ research on continental Europe has developed new method-

\footnotetext{
The Focus is the outcome of a virtual workshop hosted by the mpilhlt in June 2020. It owes its origins from the shallway and canteen discussions legal books that I enjoyed with Airton Ribeiro da Silva and Idalia García, who were guests at the Institute before the pandemic changed our lives. I am very grateful to the speakers at the workshop as well as to those who joined the discussion virtually, providing very interesting food for thought. I am particularly thankful to Pedro Rueda for his always inspiring and generous contributions to the dialogue between book history and legal history.
}

1 On the history of science approach to knowledge production that takes into account materiality, see RENN/ Damerow (2003); Blair (2010).

2 For an overview of the recent approaches to legal materiality, see Johnson (2018). See also PAes (2019) and the special issue on »Legal Materiality in Law and Text Culture«: Yoon Kang / Kendall (eds.) (2019).

3 Hespanha (2008) 12.

4 On the connection between the printing press and the law, see also Vesting (2013).

5 For some of the few early examples of legal historians paying attention to the materiality of legal books of the medieval and early modern periods, covering both continental Europe and England, see OsLer (1995, 2000); Colli (2002, 2005); BACKer (1999, 2000, 2002). From the field of history of knowledge, and with particular attention being paid to the material context of the production and circulation of legal books, see MACLEAN (1992).

6 EAmon (1994); Johns (1989); VAlleriani (2017).

7 Dauchy et al. (eds.) (2016). 
ologies for studying the dissemination of early modern legal books across borders, far beyond the author's intentions. ${ }^{8}$ In addition, the actors involved in this process as well as the role of censorship of legal books have become objects of study, ${ }^{9}$ as have jurists' readings and the authorship of legal books. ${ }^{10}$

Even though attention has focused mainly on printed books, scholars have clearly stressed the "continued existence of an important production and market of legal manuscripts in the age of printing ${ }^{11} .{ }^{11}$ Also in the area of law, manuscript and print coexisted for a long time, and manuscripts were preferred in specific cases. ${ }^{\mathbf{1 2}}$ Very recently, the materiality of medieval legal culture, combining approaches from legal history and from the history of the book, has been explored, following a "manuscript-led perspective and highlighting the importance of the "contextualization of legal texts within the materiality of the written word " in order to understand "how laws and related texts were actualized and adapted $\varkappa^{13}$ The cultural and material history approach has also been applied to the study of the most important medieval Castilian code, the Siete Partidas. Here, the analysis of the regulation of legal writing at both the normative and the documentary level has been used to explore both the techniques and the theory of medieval codification. ${ }^{\mathbf{1 4}}$

Moving to England, following the stimulating and critical debate initiated by the publication of Elizabeth Eisenstein's works, ${ }^{15}$ scholars working on the history of the common law have been exploring the »impact of the printed word on legal development ${ }^{\mathbf{1 6}}{ }^{\mathbf{1 6}}$ showing that, even though the printing press constituted »one of the most important of all episodes in Western history «, ${ }^{\mathbf{1 7}}$ it was not per se an agent of change. The introduction of printing did not automatically lead to an increase in the production of legal books. Scholars instead link the later explosion of legal books to early modern business practices, employed especially in the law book trade. They have shown that the development of printed legal material was the result of a complex interaction between lawyers, printers, the Stationers' Company and the state, and influenced by the regulatory structures that were put in place. ${ }^{\mathbf{1 8}}$

A similar approach has been adopted for studying the "production, circulation and reception of legal knowledge in China «. ${ }^{\mathbf{1 9}}$ A recent study has shown that the commercial printing revolution in early modern China fundamentally transformed the Chinese judicial system and legal culture. It concluded that commercial publishers introduced new sources of judicial authority, transformed the popular view of law and fostered popular legal awareness in Qing local society.

Of course, these studies have taken different typologies of legal books into account. On the one hand, together with the more traditional learned legal literature ${ }^{20}$ scholars have been working on official legislative texts. ${ }^{\mathbf{2 1}}$ For instance, the publication of the first royal acts in France has been analysed to explore the impact of the printing press both on legislative power and on legal practice. ${ }^{22}$ On the other hand, another particularly innovative focus of research has been on popular and pragmatic handbooks and manuals, which played a fundamental role in early modern legal literacy
8 Beck Varela (2016).

9 Beck Varela (2013).

10 SAVelli (2011); Beck Varela (2017, 2018).

11 Hespanha (2008) 15. On manuscript circulation and scribal publication in the early modern period, see Love (1993, 2013); Bouza (2001); RiCHARDSON (2009).

12 Harvey (2015) 125.

13 Gobbitt (2021) 3.

14 Velasco (2020).

15 Eisenstein (1980, 1993); JoHns (1989); MCKitTerick (2003). For the discussion, see the AHR vol. 107 Forum: Grafton (2002); EISENSTEIN (2002a, 2002b); JoHns (2002).
16 BaLOCH (2007) 390.

17 Johns (2002) 107.

18 Baloch (2007); Harvey (2015).

19 ZHANG (2020) 5.

20 Book historians have recently started to pay attention to learned legal books as well. See Panzanelli Fratoni (2020).

21 Harvey (2015) 143-239; Zhang (2020) 3-110.

22 Prévost (2018). The form of legislative texts has been explored also from the perspective of the history of the book. Cf. Ruiz García (2011). 
and allowed legal knowledge to reach a wider audience, both in European societies ${ }^{23}$ and in imperial China. ${ }^{24}$

A particular kind of pragmatic normative literature, related to the sphere of religious normativity and moral theology, played a fundamental role in normative knowledge production in Ibero-America. ${ }^{25}$ Moral theology was the new producer of normative knowledge in the early modern Iberian worlds. Pragmatic books mobilised the knowledge that was needed to produce normative statements. Through these »small« pragmatic »books«, which often came out of a web of global normative knowledge production such as the School of Salamanca, the solutions to the questions and problems that the "big empires" had to face in the turbulent decades of the 16th century circulated on a global scale. ${ }^{26}$ Only partially printed in overseas territories, the great majority of the books circulating in America were printed in Europe and then imported. For Spanish America this happened via Seville. $^{27}$

As we have seen so far, legal historians have started to look at legal books to inquire into the processes of how normative knowledge was produced in the early modern Iberian worlds, which is the object of this Focus. An entirely new field of investigation and exchange between branches of knowledge has been developed and has opened up new avenues of inquiry.

Regarding the legal culture of early modern Spanish America, looking at the materiality and, above all, at the circulation of legal books is particularly meaningful. One of the components of this multifaceted legal culture was precisely related to the Spanish and, more generally, the European learned legal tradition, which travelled from Europe to the Americas also through books. ${ }^{28}$ The construction of this legal culture was a very complex phenomenon that cannot, of course, be reduced to a mere process of reception. Rather, it was the outcome of processes of adaptation, cultural translation and sglocal knowledge production that as yet have not been fully explored. $^{29}$

So far, many studies have been dedicated to the authors and texts that circulated, as well as to the channels through which the European legal tradition reached America. ${ }^{30}$ However, not enough attention has yet been paid to the materiality and to the media dimension of these (and possibly other) legal books. Such an approach can add other dimensions to the investigation. ${ }^{31}$

I opened this introduction by mentioning that, according to historians of science, the material context of knowledge production matters. For this reason, a dialogue between book history and legal history is needed to take a step forward in the understanding of the production of normative knowledge in the early modern Iberian worlds. The categories used to analyse a book's life cycle can be particularly helpful in this regard. I am referring to Robert Darnton's »communications circuit«, which looks at book production, circulation and consumption, and which has recently been revisited by Bellingradt and Salman. Especially when we consider the normative knowledge production on the imperial scale of the Iberian worlds, where books circulated largely between the two sides of the Atlantic (and, of course, also in the Pacific parts of the empires, which, unfortunately, we could not cover with this Focus), the theoretical perspective of »books in motion" appears particularly fruitful. ${ }^{32}$ It also takes into account the "materiality, sociality, and spatiality« of the "communications circuit«. It goes without saying that in the production of normative knowledge in the Iberian worlds, the circulation and consumption of normative books played a fundamental role.

The articles of this Focus are intended as a first step into a necessary dialogue between book historians and legal historians working on legal books. In the contributions, three book historians (Pedro Rueda, Idalia García, and Natalia Maillard Álvarez) and one legal historian (Airton Ribeiro da Silva Jr.) look at legal books in the early modern
23 Korpiola (2019).

24 ZHANG (2020) 111-143.

25 Duve/ Danwerth (eds.) (2020).

26 Duve (2020) 29-31; Duve (2021).

27 DANWERTh (2020).

28 Already at the end of the 1990 s, Víctor Tau Anzoátegui stressed the importance of looking at the diffusion of legal books and the composition of colonial libraries to investigate the construction of a common reference culture. Tau Anzoátegui (1997) 73.

29 Duve (2020).

30 See in particular Barrientos Grandón (1993, 2000). For a historiographical overview of the so-called
Derecho Indiano, see Hespanha (2017).

31 Cf. Duve / Danwerth (eds.) (2020); Duve et al. (eds.) (2021).

32 Bellingradt/Salman (2017). 
Iberian worlds, covering New Spain, Brazil, the Atlantic trade, and the city of Seville.

The contributions focus on the circulation of legal books from Europe to the Americas, their use and their readers. By what routes and what means did normative books circulate in the early modern Iberian worlds? Who were the actors involved? Which editions did circulate, and in which communities of practice? How did these travelling books and their use shape legal practices? Furthermore, did the material conditions of the use of legal books in judicial activity contribute to the production of normative knowledge? Who were the readers of legal books? These are some of the questions that the articles in this Focus try to answer, making an important contribution to legal historical research by showing how questions and methods from the history of the book can fruitfully be applied to study the production of normative knowledge, too.

From the methodological point of view, the contributions mainly use contemporary documentary sources to look at one face of the "two-sided reality of bibliographic research $«, 33$ the »external history« of legal books. Amongst the archival documents analysed by the contributors are book lists prepared for different purposes, such as for the book trade, censorial control, or notarial postmortem documentation.

Pedro Rueda (Law Books in the Hispanic Atlantic World: Spaces, Agents and the Consumption of Texts in the Early Modern Period) tracks the circulation of legal books in the Atlantic world through the commercial networks and circuits of the Carrera de Indias (the system of armed convoys of ships crossing the Atlantic). He investigates the distribution channels and the activity of the agents who made the circulation of law books between Europe and the Spanish Crown's American territories possible, namely the merchants and booksellers, as well as the readers who placed the orders, who played crucial roles in the consignments of legal books printed in Europe that travelled first to, and then within, the Americas.

Rueda demonstrates how the infrastructure that enabled the circulation of law books between Europe and the Americas shaped the availability of normative knowledge stored and mobilised in legal books. Through his documentary analysis of book shipments, he is able to follow the slives of legal books that circulated between Europe and America, and the readers (jurists, theologians, professors, but also Crown officials and municipal office holders) who needed them as necessary tools for their professional activity, to continue their academic studies or to perform their duties in colonial institutions. Some of these books were >pragmatic books as well.

Idalia García (Orden dentro del desorden: circulación de libros de derecho en Nueva España, 15851640) looks at the circulation of legal books in early modern New Spain by studying the private and institutional libraries established by royal officials and religious orders. Her approach includes the analysis of book lists written by the Inquisition interested in controlling the books that entered New Spain. She studies not only the contents of the lists but also their form in order to understand how these lists worked and to decipher their meaning as cultural practices. Her analysis of the book lists has been used to create a bibliographical database for identifying early modern editions in historical documents. This allows us to identify the editions of the books which were transported from Europe to the Americas via the commercial networks, proving their actual presence in certain defined communities of practices.

Airton Ribeiro da Silva Jr. (Magistrates'Travelling Libraries: The Circulation of Normative Knowledge in the Portuguese Empire of the Late 18th Century) explores a different way in which legal books circulated in Portuguese America. In fact, he looks at the books that the magistrates, members of the Portuguese judicial administration, took with them when moving from one judicial post to another across the pluricontinental empire. Censorship sources allow him to identify and reconstruct the »travelling libraries « that these »itinerant magistrates « brought with them to help them with their temporary overseas appointments. These "portable collections « allow him to identify the indispensable working tools that the magistrates used for their judicial functions on the most remote fringes of the global Portuguese empire. 
In addition to »travelling libraries", the Focus takes into account also the private libraries of jurists and other legal professionals in early modern Spain as a way of accessing the readers of legal books. Natalia Maillard Álvarez (Lectores de obras juridicas en la Edad Moderna [Sevilla, siglos XVIXVII]) studies the readers of legal books in early modern Spain by analysing the inventories of private libraries recorded in Seville, the city that was the centre of the Atlantic trade, in the 16th and 17 th centuries. The data extracted from the notarial documents that she examines are collected in a database of asset inventories produced between 1550 and 1634. Maillard Álvarez traces the profiles of a diverse range of readers who collected legal books - both legal professionals, with or without university legal education, and those outside the world of law - and discusses the kinds of legal books preserved in their libraries in the late Spanish Renaissance.

Legal books were essentially working tools. The articles in this Focus provide complementary pictures of legal books in motion in the early modern Iberian worlds from different observation points: books stored in private libraries in Seville, composing the sportable libraries travelling with magistrates in Portuguese America, crossing the Atlantic in the commercial book trade, or travelling from Europe to reach libraries of religious orders in New Spain.
These contributions show that looking at legal books as material objects and analysing them in motion< can open up new research paths to better understand the factors that contributed to normative knowledge production in the early modern Iberian worlds. For instance, it appears crucial to assess the impact of the logics and actors of the book market on the production of normative knowledge, or to investigate the interaction between the material conditions in which legal professionals performed and the production of normative knowledge across continents. Moreover, due to the "epistemic indeterminacy « ${ }^{34}$ of early modern books and the differences in form and content between editions, the identification of the specific editions of legal books present in certain defined epistemic communities could also contribute to identifying the normative knowledge available. Finally, outlining the profile of the readers of legal books in motion', who were the "main performer[s] of every process of reception or creative appropriation of a text in a different context ${ }^{35}$ could allow us to access another level of normative knowledge production by observing in detail how suniversak legal knowledge was transformed and adapted to concrete local contexts.

\section{Bibliography}

- Backer, John Hamilton (1999), The Books of the Common Law, in: Hellinga, Lotte, J. B. Trapp (eds.), The Cambridge History of the Book in Britain, Vol. 3: 1400-1557, Cambridge, 411-432

- Backer, John Hamilton (2000), The common law tradition. Lawyers, books and the law, London

- Backer, John Hamilton (2002), English Law Books and Legal Publishing, in: Barnard, John, D. F. McKenzie (eds.), The Cambridge History of the Book in Britain, vol. 4: 1557-1695, Cambridge, 474-503

- Baloch, Tariq A. (2007), Law Booksellers and Printers as Agents of Unchange, in: Cambridge Law Journal 66,2, 389-421

- Barrientos Grandón, Javier (1993), La cultura jurídica en la Nueva España, Mexico

- Barrientos Grandón, Javier (2000), Historia del derecho indiano, Roma

- Beck Varela, Laura (2013), Literatura jurídica y censura: Fortuna de Vinnius en España, Valencia

- Beck Varela, Laura (2016), The Diffusion of Law Books in Early Modern Europe: A Methodological Approach, in: Meccarelli, Massimo, María Julia Solla Sastre (eds.), Spatial and Temporal Dimensions for Legal History. Research Experiences and Itineraries (Global Perspective on Legal History 6), Frankfurt am Main, 195-239, http://dx.doi.org/10.12946/ gplh6

34 JoHns (1998) 36.

35 Beck Varela (2016) 201. On the active role of the reader in the production of meaning, see e.g. Chartier (1992). 
- Beck Varela, Laura (2017), Authorship in Early Modern Jurisprudence. Paul Voet (1619-1667) on auctor and editor, in: Quaerendo 47, 252-277

- Beck Varela, Laura (2018), >Memoria de los libros que son necesarios para pasar $<$ Lecturas del jurista en el siglo XVI ibérico, in: CIAN - Revista de Historia de las Universidades 21,2, 227-267, https://doi.org/10.20318/cian.2018.4476

- Bellingradt, Daniel, Jeroen Salman (2017), Books and Book History in Motion: Materiality, Sociality and Spatiality, in: Bellingradt, Daniel et al. (eds.), Books in Motion in Early Modern Europe. Beyond Production, Circulation and Consumption, Cham, 1-11

- Blair, Ann (2010), Too Much to Know. Managing Scholarly Information before the Modern Age, New Haven

- Bouza, Ferdinando J. (2001), Corre manuscrito: una historia cultural del Siglo de Oro, Madrid

- Chartier, Roger (1992), L’ordre des livres. Lecteurs, auteurs, bibliothèques en Europe entre XIVe et XVIIIe siècle, Aix-enProvence

- Colli, Vincenzo (2002), Juristische Buchproduktion im Mittelalter, Frankfurt am Main

- Colli, Vincenzo (2005), Giuristi medievali e produzione libraria, Stockstadt am Main

- Danwerth, Otto (2020), The Circulation of Pragmatic Normative Literature in Spanish America (16th-17th Centuries), in: Duve / Danwerth (eds.), 89-130

- Dauchy, Serge et al. (eds.) (2016), The Formation and Transmission of Western Legal Culture. 150 Books that Made the Law in the Age of Printing, Cham

- Duve, Thomas (2020), Pragmatic Normative Literature and the Production of Normative Knowledge in the Early Modern Iberian Empires (16th-17th Centuries), in: Duve/ Danwerth (eds.), 1-39

- Duve, Thomas (2021), The School of Salamanca. A Case of Global Knowledge Production, in: Duve et al. (eds.), 1-42

- Duve, Thomas, Отto Danwerth (eds.) (2020), Knowledge of the pragmatici: Legal and Moral Theological Literature and the Formation of Early Modern Ibero-America, Leiden

- Duve, Thomas, José Luis Egío, Christiane Birr (eds.) (2021), The School of Salamanca: A Case of Global Knowledge Production, Leiden

- Eamon, William (1994), Science and the Secrets of Nature. Books of Secrets in Medieval and Early Modern Culture, Princeton

- Eisenstein, Elizabeth (1980), The Printing Press as an Agent of Change, Cambridge

- Eisenstein, Elizabeth (1993), The Printing Revolution in the Early Modern Europe, Cambridge

- Eisenstein, Elizabeth (2002a), An Unacknowledged Revolution Revisited, in: The American Historical Review 107,1, 87-105

- Eisenstein, Elizabeth (2002b), [How to Acknowledge a Revolution] Reply, in: The American Historical Review 107,1, $126-128$

- Goввітт, Тном (2021), Introduction: Law|Book|Culture in the Middle Ages, in: IDEm (ed.), Law|Book|Culture in the Middle Ages (Explorations in Medieval Culture, vol. 14), Leiden, 1-13

- Grafton, Anthony (2002), How Revolutionary was the Print Revolution?, in: The American Historical Review 107,1, 84-86

- Harvey, David J. (2015), The Law Emprynted and Englysshed: The Printing Press as Agent of Change in Law and Legal Culture, 1475-1642, Oxford

- Hespanha, António Manuel (2008), Form and content in early modern legal books. Bridging the gap between material bibliography and the history of legal thought, in: Rechtsgeschichte - Legal History 12, 12-50, https://doi.org/10.12946/rg12/ 012-050

- Hespanha, António Manuel (2017), O sdireito de Índias« no contexto da historiografia das colonizações ibéricas, in: Duve, Thomas (ed.), Actas del XIX Congreso del Instituto Internacional de Historia del Derecho Indiano, Berlín 2016, Madrid, vol. 1, 43-86

- Infantes, Victor (2012), La >muestra de impresión`: un testimonio inédito de la estrategia editorial del Siglo de Oro, in: Cayuela, Anne (ed.), Edición y literatura en España (Siglos XVI y XVII), Zaragoza, 137-168

- Johns, Adrian (1998), The Nature of the Book. Print and Knowledge in the Making, Chicago

- Johns, Adrian (2002), How to Acknowledge a Revolution, in: The American Historical Review 107,1, 106-125

- Johnson, Tom (2018), Legal History and the Material Turn, in: Dubber, Markus D., Christopher Tomlins (eds.), The Oxford Handbook of Legal History, Oxford

- Korpiola, Mia (2019), Legal Literacy in Premodern European Societies, Cham

- Love, Harold (1993), Scribal Publications in Seventeenth-Century England, Oxford

- Love, Harold (2013), The Manuscript after the Coming of Print, in: Suarez, Michael F., H. R. Woudhuysen (eds.), The Book. A Global History, Oxford, 197-204

- Maclean, IAn (1992), Interpretation and Meaning in the Renaissance. The Case of Law, Cambridge

- McKitterick, David (2003), Print, Manuscript and the Search for Order, 1450-1830, Cambridge

- Osler, Douglas (1995), Text and Technology, in: Rechtshistorisches Journal 14, 309-331

- Osler, Douglas (2000), A bibliography of European legal literature to 1800, Frankfurt am Main

- Paes, Mariana Armond Dias (2019), Legal Files and Empire: Form and Materiality of the Benguela District Court Documents, in: Administory 4, 53-70

- Panzanelli Fratoni, Maria Alessandra (2020), Printing the Law in the 15th Century. With a Focus on Corpus iuris civilis and the Works of Bartolus de Saxoferrato, in: Dond, Cristina (ed.), Printing R-Evolution and Society 1450-1500: Fifty Years that Changed Europe, Venezia, 47-197

- Prévost, Xavier (2018), Les premières lois imprimées. Étude des actes royaux imprimés de Charles VIII à Henri II (1483-1559), Paris

- Renn, Jürgen, Peter Damerow (2003), The Hanging Chain: A Forgotten »Discovery« Buried in Galileo's Notes on Motion, in: Holmes, Frederic L. et al. (eds.), Reworking the Bench. Research Notes in History of Science, Dordrecht, 1-24

- Richardson, Brian (2009), Manuscript Culture in Renaissance Italy, Cambridge 
- Rueda Ramírez, Pedro (2017), El derecho en los catálogos de venta de los libreros sevillanos: la circulación de impresos jurídicos en el mundo atlántico (1680-1689), in: Duve, Thomas (coord.), XIX Congreso del Instituto Internacional de Historia del Derecho Indiano, Berlin 2016, Madrid, vol. I, 453-474

- Ruiz García, Elisa (2011), La balanza y la Corona. La simbólica del poder y los impresos jurídicos castellanos (1480-1520), Madrid

- Savelli, Rodolfo (2011), Censori e giuristi. Storie di libri, di idee e di costumi (secoli XVI-XVII), Milano

- Tau Anzoátegui, Víctor (1997), Nuevos horizontes en el estudio historico del derecho indiano (XI Congreso del Instituto Internacional de Historia del Derecho Indiano), Buenos Aires

- Valleriani, Matteo (ed.) (2017), The structures of practical knowledge, Cham

- Velasco, Jesús R. (2020), Dead Voice. Law, Philosophy, and Fiction in the Iberian Middle Ages, Philadelphia

- Vesting, Thomas (2013), Die Medien des Rechts, vol. 3: Buchdruck, Weilerswist

- Yoon Kang, Hyo, Sara Kendall (eds.) (2019), Legal Materiality, in: Law Text Culture (special issue) 23

- Zhang, Ting (2020), Circulating the Code. Print Media and Legal Knowledge in Qing China, Seattle 